Ks. STANISŁAW PIECH

\title{
KULT MATKI BOŻEJ NIEUSTAJĄCEJ POMOCY W KOŚCIELE REDEMPTORYSTÓW W KRAKOWIE-PODGÓRZU
}

W liturgiczne wspomnienie św. Alfonsa de Liguori, dnia 2 sierpnia 1903 r. „ojcowie rychło rano odprawili Msze św. w parafialnym kościele” zanotował w Kronice domu sługa Boży o. Bernard Lubieński. „Ponieważ książę kardynał Puzyna właśnie w tejże chwili był zamurowany w konklawe przed wyborem ojca św. Piusa X (4 VIII) z jego poręki kochany nasz biskup ks. Anatol Nowak zjechawszy o ósmej rano do parafialnego kościoła, poprowadził procesya $\mathrm{z}$ obrazem, $\mathrm{z}$ Rzymu sprowadzonym, a przez czterech naszych ojców na noszach niesionym, do kaplicy naszej. Tu najpierw Ks. Biskup odbył obrządek poświęcenia kaplicy pod tytułem M[atki] B[oskiej] Nieustającej Pomocy. Następnie zawieszono nad ołtarzem obraz i Ks. Biskup wygłosił w nader gorących i nam aż za życzliwych słowach kazanie. Winszując podgórzanom, że nas mają, winszując i nam żeśmy tu objęli posterunek nowy dla pracy misjonarskiej"1.

\section{NA RĘKACH REDEMPTORYSTÓW DO ROBOTNICZEGO ŚWIATA}

Podgórski obraz Matki Bożej Nieustającej Pomocy, wykonany w Rzymie w 1903 r., pobłogosławiony przez papieża Leona XIII dnia 18 kwietnia owego roku przywiózł do Krakowa sługa Boży Bernard Łubieński, niezwykle zasłużony w rozkrzewianiu kultu maryjnego związanego z tym wizerunkiem².

${ }^{1}$ Archiwum Klasztoru Redemptorystów w Krakowie (dalej: ARK), rkps [bez sygn.] Kronika domu Zgromadzenia Najśw. Odkupiciela pod wezwaniem Matki B[oskiej] Nieust [ajacej] Pomocy w Krakowie na Podgórzu, t. 1 (1900-1913), s. 21; por. "Litterae Annales de Rebus Gestis Provinciae Pragensis Congregationis SS. Redemptoris", 3:1903, s. 54.

${ }^{2}$ A. B a z i e l i c h, Stuga Boży o. Bernard Eubieński, Apostol kultu Matki Boskiej Nieustajqcej Pomocy, Tuchów 1995, s. 16-52. 
Obraz ten, wierna kopia rzymskiej ikony z kościoła św. Alfonsa w Wiecznym Mieście, posiadający te same co oryginał wymiary $(53 \times 41 \mathrm{~cm}$.), został wykonany na desce mahoniowej, zagruntowanej i złoconej. Kopię tę w $W y$ kazie rzymskim odnotowano pod numerem 2733. Ufundowały ja dwie służące z pobliskiej Wieliczki. Były to Regina Dajdówna i Franciszka Piątków$\mathrm{na}^{3}$. Po poświęceniu kamienia węgielnego pod klasztor dnia 21 września 1902 r. „stawiły się same przed o. wizytatorem Teofilem Pasurem i prosiły czyby im pozwolił dać na obraz ze Rzymu"4. Po sprowadzeniu obrazu złożyły na ten cel ofiarę w wysokości 400 koron, po 200 koron każda. W sytuacji materialnej biednych służących nie było to wcale mało. W owym czasie dzienny zarobek mistrza murarskiego wynosił 4-8 koron.

Dlaczego kard. Jan Puzyna i redemptoryści wybrali Podgórze na miejsce osiedlenia Zgromadzenia Najśw. Odkupiciela w diecezji krakowskiej? Pod koniec XIX stulecia Podgórze z obrębnego miasta rzemieślniczo-rolniczego przekształciło się w ośrodek przemysłowy. Powstawały tam liczne fabryki i różnego rodzaju zakłady przemysłowe a wraz z nimi rosła klasa robotnicza, boleśnie wyzyskiwana przez kapitalistów. Robotnicy żyjący w nędzy byli szczególnie podatni na rozwiniętą $\mathrm{w}$ tym środowisku propagandę socjalistyczna. Podgórze $w 1900 \mathrm{r}$. „,było w kwitnącym stanie materialnym tak iż żadnych podatków dodatkowych w mieście nie pobierano" - pisał w Kronice domu sługa Boży Bernard tubieński. „Załoga wojskowa, stacja wielka kolejowa Podgórze-Płaszów; wielki młyn im. Barucha, wapienniki i ceglarnie, gimnazjum itd. przyczyniły się do tego. Zbliżenie do Krakowa przez dwa mosty, sprawia, że dla taniego życia tu jest napływ wielki robotników, rzemieślników i czeladników wszelkiego kalibru, słowem proletariat i żydowstwo. To też moralna strona miasta nieświetnie się przedstawiała. Socjalizm się rozpanoszył. Rzezimieszki krakowskie tu mają swoje nory. Żydostwo żyjące z demoralizacji i z wódki tu ma swoje zyski. Socjaliści mają tu swoje kryjówki. Tymczasem przy kościele parafialnym, zaszczupłym na coraz bardziej rozrastająca się ludność, a do tego i grożącym ruiną jest tylko proboszcz z trzema wikarymi i dwoma katechetami. Parafia zaś podgórska, oprocz miasta obejmuje dziewięć wiosek i liczy przeszło 17 tys. dusz. Prawda, że za Wisłą zaraz jest Krakow ze swymi przelicznymi świattyniami i klasztorami; ale w samym Podgórzu, procz maluczkiego domku ss. felicjanek i to bez mszalnej kaplicy, klasztora nie ma żadnego, a dopiero o pięć kilometrów w Lagiewnikach przytułek dla upadłych niewiast u sióstr Matki Miłosiernej, fundacja księcia Aleksandra Lubomirskiego"5. W Podgórzu dotkliwie odczuwano brak klasztoru kleryckiego, który mógłby pomóc w trudnym duszpasterstwie robotników żyjących często w nędzy i religijnie zaniedbanych. Kard. Jan Puzyna w korespondencji (1 I 1900) z o. Bernardem

\footnotetext{
${ }^{3}$ ARK, rkps [bez sygn.] Accepta et expensa domus Cracoviensis 1900-1912, s. 6.

${ }^{4}$ ARK, rkps [bez sygn.] Kronika domu..., t. 1, s. 22.

${ }^{5}$ Tamże, s. 6-7.
} 


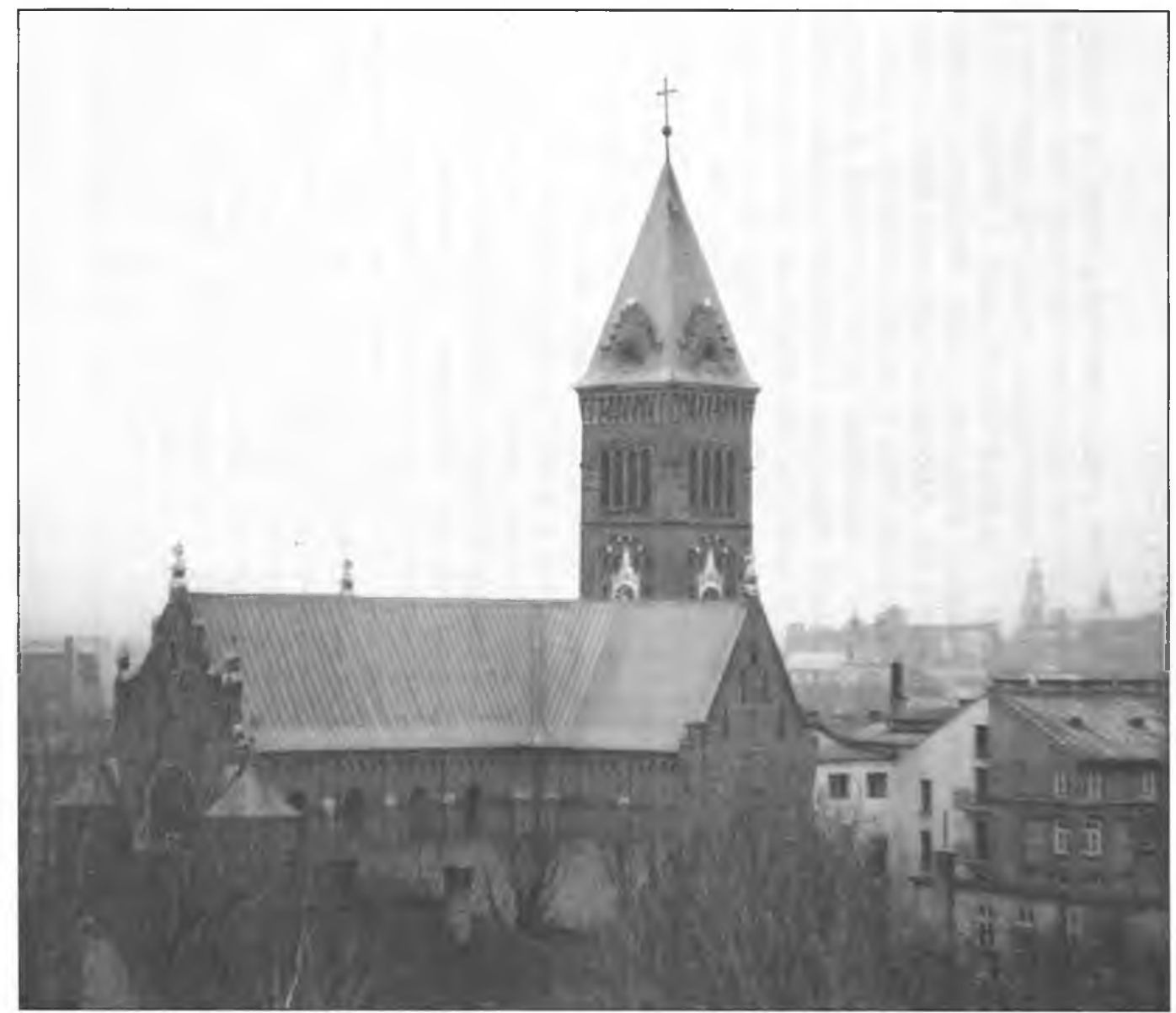

1. Kościół Redemtorystów w Krakowie-Podgórzu. 
Łubieńskim, z którym od lat pozostawał w przyjaźni wyraził pragnienie, „aby w diecezji św. Stanisława Wasz zakon jak najrychlej założył dom zakonny" W 1903 r. osiedli tam redemptoryści.

\section{POCZĄTKI KULTU}

Redemptoryści od początku swoją pracę apostolską łączyli z Maryja, Matką Nieustającej Pomocy. Obraz Jej był już wcześniej znany mieszkańcom Podgórza, ponieważ jego papierowa kopia wisiała w kościele parafialnym. W niedzielę 25 października 1903 r. na mocy dekretu kard. J. Puzyny z dnia 21 tegoż miesiąca zostało w kaplicy Redemptorystów zawiązane bractwo Matki Bożej Nieustającej Pomocy i św. Alfonsa. „Wprawdzie setki, a nawet może tysiące podgórzan już zapisanych było w księdze brackiej w Mościskach, jako członki tegoż bractwa" - zanotował o. B. Łubieński w Kronice klasztoru podgórskiego. „Bo wikary dawny ks. Ludwik Przygłudek bardzo gorliwie zajął się przez lat wiele skupianiem ludu tutejszego około obrazu tej naszej ukochanej matki w kościele parafialnym w Podgórzu. Jednakowoż bractwa kanonicznie miejscowego tu nie było"'. W dniu 3 grudnia 1903 r. do bractwa wpisał się wspomniany wyżej Anatol Nowak, biskup pomocniczy diecezji krakowskiej wraz z 36 klerykami, którzy wraz z nim przybyli do kaplicy. Przed obrazem Matki Bożej Nieustającej Pomocy odśpiewali Veni Creator. Zostali wpisani do księgi brackiej i otrzymali medaliki brackie, poczym zaśpiewali Te Deum laudamus i zostali pobłogosławieni Najśw. Sakramentem $^{8}$. W tym też miesiącu bractwo zostało afiliowane do arcybractwa w Rzymie. W krótkim czasie podgórska kaplica zakonna stała się ośrodkiem kultu Matki Bożej Nieustającej Pomocy, cieszącego się wielkim wzięciem nie tylko wśród miejscowych wiernych, ale również z Krakowa i okolic. Bractwo intesywnie się rozwijało. W 1903 r. liczyło ono 865 członków. W następnym roku przyjęto 2470 nowych, a w 1905 r. aż 5300 . Z końcem 1905 r. bractwo liczyło 8600 członków. Ogółem w księgach brackich z lat 1903-1960 odnotowano 56630 nazwisk. W okresie Polski Ludowej, w warunkach walki z Kościołem, programowej ateizacji i laicyzacji życia społecznego władze państwowe rozwiazały wszelkie organizacje katolickie. Ostatniego wpisu do bractwa dokonano 22 sierpnia $1960 \mathrm{r}^{9}$. Członkowie bractwa spotykali się jednak nadal, chociaż nie formalnie, w każdą drugą niedzielę miesiąca $\mathrm{w}$ ramach kół róż żywego różańca, a także na nabożeństwach nieustannej nowenny.

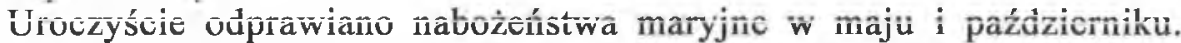
W dniu „30 kwietnia 1904 rozpoczęty został pierwszy nasz miesiąc Maryi na

${ }^{6}$ Tamże s. 4.

${ }^{7}$ ARK, rkps [bez sygn.] Kronika domu..., t. 1, s. 29.

${ }^{8}$ ARK, rkps [bez sygn.] Kronika domu..., t. 1, s. 36.

9 Archiwum Parafii Matki Bożej Nieustającej Pomocy w Krakowie-Podgórzu (dalej: APMNP), Spisy cztonków Bractwa Matki Bożej Nieustajacej Pomocy $i$ Świętego Alfonsa, t. $1-3$. 
podgórzu: litania [loretańska], kazanie i błogosławieństwo [Najśw. Sakramentem] o w pół do siódmej wieczór. O. [Stanisław] Chochleński o M[atce] B[oskiej] Nieust[ającej] Pomocy miewał kazania" - zapisał sługa Boży Bernard Lubieński. „Ludu pełno było prawie jak w niedziele aż do końca miesiąca"10.

$\mathrm{Na}$ odpust przychodziły liczne grupy pielgrzymów z Krakowa i z okolicy. W latach 1904-1906 wybudowano duży neogotycki kościół według projektu Jana Sas Zubrzyckiego" . „Aby zebrać na budowę nieco grosza dano w Pradze wydrukować 25000 dużych obrazów M[atki] B[oskiej] N[ieustającej] Pomocy" - napisał o. Władysław Szołdrski, znany historyk zgromadzenia. „Za tych którzy by otrzymując je złożyli jaką ofiarę na budowę kościoła, miała się po wieczne czasy odprawiać co tydzień jedna Msza św. I rzeczywiście owe obrazy stały się głównym źródłem, z którego czerpano" 12 . Redemptoryści głoszący misje i rekolekcje w różnych parafiach poszczególnych zaborów szerzyli kult Najśw. Maryi Panny i rozprowadzali wspomniane obrazy wśród wiernych ${ }^{13}$. Ofiary jakie wierni składali nabywając te wizerunki w znacznie wspomagały budowę świątyni. Trzynawowy neogotycki kościół, z elementami neoromańskimi (kolumny i kapitele) zbudowano na planie krzyża. Nawa główna została zamknięta półkolistą absydą. W dniu 8 września 1906 r. bp A. Nowak konsekrował nowo zbudowany kościół pod wezwaniem Matki Bożej Nieustającej Pomocy. W latach 1907-1908 Wójcik, nauczyciel szkoły rzeźbiarskiej w Zakopanem wykonał kryty baldachimem ołtarz główny, w którym na centralnym miejscu zawieszono wspomnianą ikonę $^{14}$. W cieniu podgórskiego obrazu Matki Boskiej Nieustającej Pomocy wielu ludzi wypraszało sobie świętość życia. Byli wśród nich bł. Aniela Salawa i wielokrotnie wspominany sługa Boży Bernard Lubieński.

Od samego początku wprowadzenia nabożeństwa do Matki Bożej Nieustającej Pomocy wytworzyła się praktyka składania przez wiernych pisemnych próśb i podziękowań odczytywanych publicznie w każdą drugą niedzielę miesiąca. Pozostały one wymownym świadectwem pobożności maryjnej i nadzwyczajnych nieraz łask, jakie wypraszali sobie modlący się do Maryi w Jej podgórskim obrazie. Materialnym wyrazem wdzięczności za otrzymane łaski pozostały liczne wota składane przed obrazem, których doliczono sie około $800^{15}$. Najcenniejszym $\mathrm{z}$ nich pozostanie jednak kościoł zbudowany $\mathrm{z}$ ofiar czcicieli Maryi i starannie odnowiony w latach 1971-1972.

${ }^{10}$ ARK, rkps [bez sygn.] Kronika domu..., t. 1, s. 48.

${ }^{11}$ M. B ru dz i s z, Redemptoryści w Krakowie 1903-1993, Kraków 1994, s. 34-35.

${ }^{12}$ W. S z o ld r s k i, Redemptoryści w Polsce, cz. 2, s. 6, (mps w Bibliotece Seminarium Duchownego Redemptorystów w Tuchowie).

${ }_{13}$ "Litterae Annales de Rebus Gestis Provinciae Polonicae Congregationis SS. Redemptoris" $1: 1910$, p. 26.

${ }^{14}$ ARK, rkps [bez sygn.] Kronika domu..., t. 1, s. 156-157-1; W. S z ołdrsk i, Redemptoryści w Polsce, cz. 2, s. 6; M. B r u d zi is zedemptoryści w Krakowie, s. 34-35.

15 Archiwum Parafii Matki Boskiej Nieustającej Pomocy w Krakowie, na Podgórzu (dalej: APMNP), rkps [bez sygn.] Spis wotów ofiarowanych Matce Boskiej Nieustającej Pomocy w klasztorze OO. Redemptorystów w Podgórzu. 


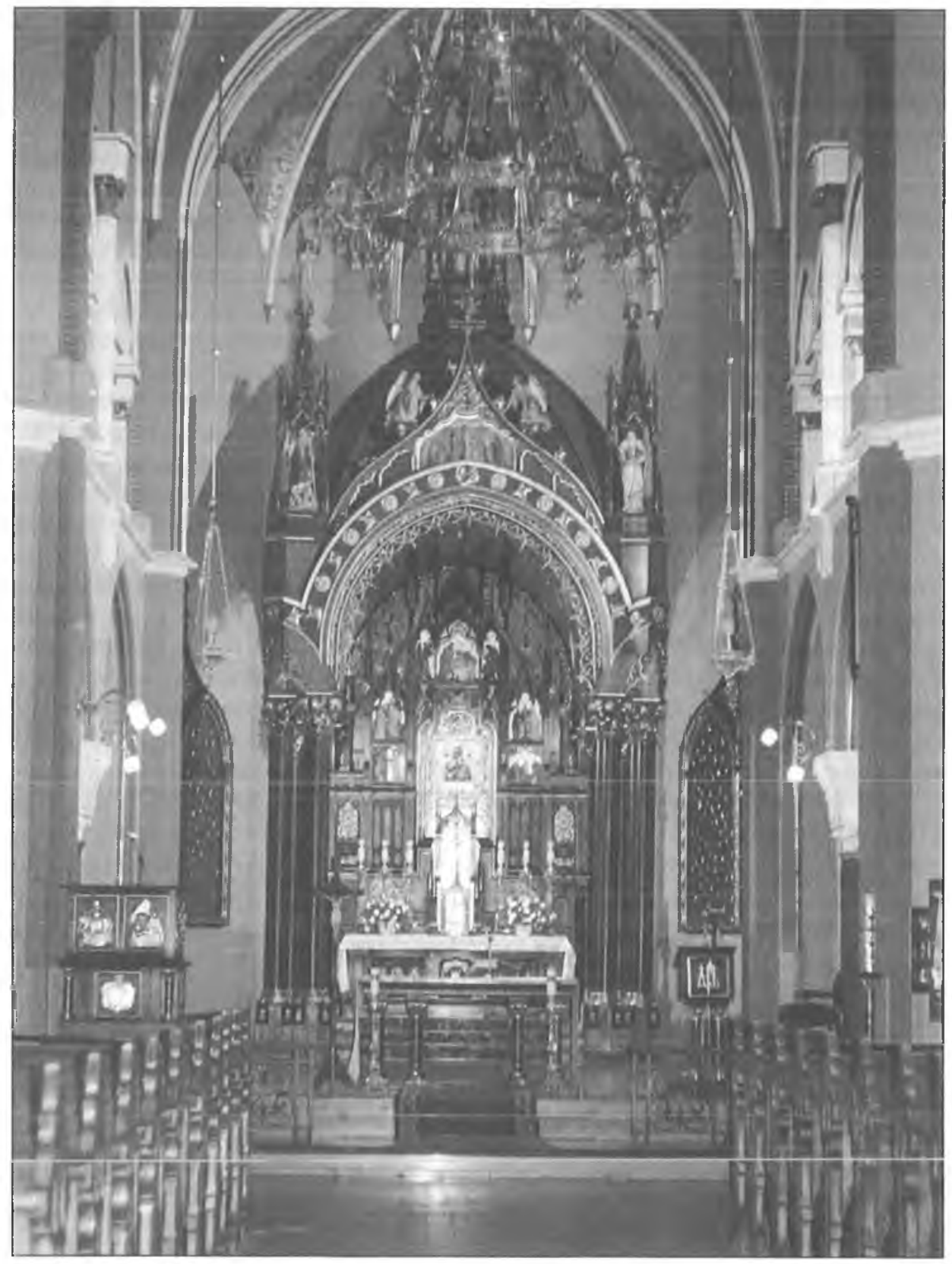

2. Wielki ołtarz z ikoną Matki Bożej Nieustajacej Pomocy w kościele Redemptorystów w Krakowie-Podgórzu. 
Wydarzeniem zwrotnym w rozwoju kultu Matki Bożej Nieustającej Pomocy na Podgórzu było wprowadzenie nabożeństwa nieustannej nowenny, polegającego na wspólnej modlitwie przed Jej ikoną w wybranym dniu każdego tygodnia w celu uproszenia jakiejś specjalnej łaski. Ta forma pobożności maryjnej zrodziła się w 1922 r. w Stanach Zjednoczonych, w kościele Redemptorystów pod wezw. św. Alfonsa de Liguori w San Louis, Mo., gdzie o. Andrew Browne wprowadził cotygodniowe nabożeństwa do Matki Bożej Nieustającej Pomocy. Praktyka ta została przez o Henry'ego Suttona nazwana nieustannq nowenna. W Polsce wprowadzono ją dopiero w $1951 \mathrm{r}$. w kościele Redemptorystów w Gliwicach. Uczynił to o. Stanisław Szczurek. W Krakowie nabożeństwo to, jako drugie w kraju, po odpowiednim przygotowaniu wiernych, zostało wprowadzone w kościele Redemptorystów na Podgórzu w dniu 24 września $1952 \mathrm{r}$. Wydarzenie to, niezwykle ważne dla spotęgowania tam kultu maryjnego szczegółowo opisał o. Tadeusz Ozga, kronikarz domowy. „Nadszedł upragniony dzień rozpoczęcia nieustannej nowenny - co chwilę dzwoni telefon z rożnych biur, dopytują się urzędnicy o godzinę rozpoczęcia nabożeństwa. Frekwencja na nabożeństwie przeszła wszelkie oczekiwania. Choć to dzień powszedni kościół wypełniony wiernymi czcicielami $\mathrm{M}$ [atki] B[oskiej] N[ieustającej] P[omocy], którzy przybyli ze wszystkich dzielnic Krakowa. Do skarbonki napłynęło 362 prośby i 50 podziękowań, jak na pierwszy raz liczba imponująca. [...] Kilka minut przed dziewiętnastą wyszliśmy procesjonalnie do drzwi kościoła by przywitać nadjeżdżającego ks. bpa Stanisłwa Rosponda. Skoro się zjawił wprowadzono go uroczyście do kościoła przy dźwiękach trąb i organów. Potem, jak zwykle wystawienie Hostii i odmówienie pierwszej modlitwy rzymskiej do M[atki] $\mathrm{B}$ [oskiej] N[ieustającej] P[omocy]". Następnie kilkadziesiąt dziewczynek w bieli i w krakowskich strojach wraz z ministrantami odśpiewało rzewną pieśń „Daj mi Jezusa". „[...] Kazanie, które miało miejsce po śpiewie dzieci wygłosił o. Ryszard Szczurek. Na niego również spadł miły zaszczyt odczytania prośb i podziękowań. Gdy skończył, asysta odmówiła na przemian z ludem wezwania do M[atki] B[oskiej] N[ieustającej] $\mathrm{P}$ [omocy] ułożone na sposób litanii. [...]. Wzruszający był moment, gdy mały ministrant Stanisław Kowalczyk odśpiewywał znane wszystkim trzykrotne wezwanie „Matko Pomocy Nieustającej proś Boga za nami”. [...] Nabożeństwo zakończono błogosławieństwem Najświętszym Sakramentem i pieśnią »Gdy trwoga nas ogarnie«, którą wszyscy umieją w Krakowie śpiewać"16.

Charakterystyczną cechą nowenny nieustannej jest składanie przez wiernych pisemnych próśb i podziękowań, które następnie są czytane publicznie w czasie nabożeństwa. Czciciele Maryi przynoszą przed Jej obraz wszystkie swoje troski, kłopoty i zmartwienia. Szukają u Niej ratunku w nieszczęściach, wsparcia i opieki. Serdecznie dziękują za otrzymane ła-

${ }^{16}$ ARK, rkps [bez sygn.] Kronika domu..., t. 5, s. 250-252. 
ski. Modlitwy te tchną niezwykle autentyczną żarliwością wiary, zaufania i wdzięczności. Nabożeństwo nowenny nieustannej odprawiane uroczyście w każdą środę od początku cieszyło się wielką popularnością, która nie zmalała aż do naszych czasów.

Kult Matki Bożej Nieustającej Pomocy rozszerzający się na całym świecie, dynamicznie rozwijał się także w krakowskim kościele Redemptorystów. „Nowenna nieustanna odprawiana w każdą środę, dwa razy w ciągu dnia" (o godzinie ósmej i osiemnastej), gromadziła licznych wiernych, którzy u Maryi szukali pomocy i opieki w różnych sytuacjach życiowych. Ranne nabożeństwa skupiają przed obrazem 200-250 osób. Natomiast na wieczorne przychodziło 300-350 wiernych. Wśród nich znajdowały się całe rodziny. Szczególnie uroczyście obchodzono rocznicę założenia tego nabożeństwa, co nie pozostało bez wpływu na jego dalszy rozwój. We środę 26 września 1962 r. pod przewodnictwem ks. Juliana Groblickiego biskupa pomocniczego archidiecezji krakowskiej, obchodzono dziesięciolecie wprowadzenia nowenny nieustannej. Przy tej okazji zliczono wszystkie teksty modlitw złożonych w tym okresie przez wiernych i okazało się że osiagnęły one imponującą liczbę 86 396, w tym 16378 podziękowań za otrzymane różne łaski, nieraz bardzo wielkie. „Tak wielka ilość udokumentowanych spotkań ludzi będących w różnych potrzebach z Matką Bożą w Jej obrazie na krakowskim Podgórzu jest wymownym dowodem szczególnego kultu tego obrazu, a zarazem świadectwem wyjątkowej obecności na tym miejscu Maryi - Matki Bożych łask" $"$.

\section{W DUSZPASTERSTWIE PARAFIALNYM}

Kult Matki Bożej Nieustającej Pomocy rozwinął się jeszcze bardziej, gdy przy kościele Redemptorystów utworzono ośrodek duszpasterski. Ustanowienie tego ośrodka zbiegło się z założeniem tam nowenny nieustannej. Uroczystości przewodniczył kard. Karol Wojtyła, który sprawując Eucharystię przed ikoną Maryi dziękował Bogu za całe bogactwo łask, jakiego za Jej przyczyną doświadczali wierni modlący się na tym miejscu. W $1978 \mathrm{r}$. wespół z sługą Bożym Janem Pietraszką biskupem pomocniczym archidiecezji krakowskiej świętowano siedemdziesięciopięciolecie przybycia redemptorystów do Krakowa a wraz z nimi ikony Matki Pomocy Nieustannej. Była to znów okazja do pielgrzymowania na Podgórze czcicieli Maryi z całego Krakowa i okolic. Uroczystość zakończyła się procesja z łaskami słynacym obrazem zdjętym z wielkiego ołtarza. „Chciano - napisał kronikarz klasztorny powtórzyć po siedemdziesięciu pięciu latach procesję, w której Matka Boża wstapiła po raz pierwszy na swój tron w tym kościele"18. Nabożeństwo do

${ }^{17}$ ARK, rkps [bez sygn.] Prośba o poparcie starań o koronację obrazu Matki Bożej Nieustajacej Pomocy w kościele Redemptorystów w Krakowie przedłożona Konferencji Plenarnej Episkopatu Polski [25-26 XI 1993], s. 3., kopia.

${ }_{18}$ ARK, rkps [bez sygn.] Kronika klasztoru (1971-1982). 
Maryji jeszcze bardziej wzmogło się, gdy w dniu 18 marca 1983 r. erygowano przy kościele parafię pod wezw. Matki Bożej Nieustającej Pomocy ${ }^{19}$. W ogłoszonym przez Ojca Swiętego Jana Pawła II Roku Maryjnym 1987/88 Matka Boża w kopii czczonej w kościele ikony - za zezwoleniem kard. Franciszka Macharskiego - odwiedziła wszystkie rodziny w parafii. Owocem tej perygrynacji ikony było około 700 rodzinnych zobowiązań i deklaracji życia chrześcijańskiego. Co roku w dniu drugiego lutego w święto Ofiarowania Pańskiego pielgrzymują do Matki Bożej Nieustającej Pomocy pracownicy krakowskiego Miejskiego Przedsiębiorstwa Komunikacji. Tradycją podgórskiego kościoła Redemptorystów stały się już te msze tramwajarskie odprawiane od 1976 r.,(wcześniej bywały w kościele pod wezwaniem św. Józefa). Na te nabożeństwa przybywał kard. Karol Wojtyła, a potem jego następca lub któryś z biskupów pomocniczych. Pielgrzymki te nabierały szczególnego wyrazu po powstaniu „Solidarności”, a potem w trudnym okresie stanu wojennego, kiedy żarliwie modlono się za ojczyznę ${ }^{20}$. W 1991 r. staraniem proboszcza o. Michała Reinkego, dokonano odnowienia i konserwacji ikony. Prace te wykonali Adam Kruk i Juliusz Kasper z Pracowni Konserwacji Zabytków na Wawelu. We środę 19 czerwca owego roku kard. F. Macharski poświęcil obraz i odprawił przed nim nowennę nieustanna ${ }^{21}$.

\section{ŚWIADECTWA OJCA ŚWIĘTEGO JANA PAWŁA II}

Wydarzeniami o niezwykłym znaczeniu dla dziejów kultu podgórskiej ikony Matki Boskiej Nieustającej Pomocy pozostały świadectwa Ojca Świętego Jana Pawła II. W 1968 r., kard. Karol Wojtyła w kazaniu w czasie Nawiedzenia Obrazu Matki Bożej Częstochowskiej w kościele Redemptorystów w Krakowie podkreślił żywy kult tej ikony wśród krakowian i złożył wymowne świadectwo swojej osobistej z nią więzi, gdy w czasie okupacji niemieckiej pracował w fabryce sody "Solway” w Borku Fałęckim. Warto przytoczyć to świadectwo. „Wiem, że tu się często gromadzą krakowianie, zwłaszcza z tej części Krakowa, zwłaszcza z Podgórza, z Borku, Ludwinowa, że się gromadzą w środy, że tutaj się modlą. Modlą w ramach tej Nieustającej Nowenny do Matki Nieustającej Pomocy, że tutaj doznają i doświadczają tej prawdy jaka się wyraża w tytule Maryi - Matka Nieustającej Pomocy mówił pasterz Kościoła krakowskiego. Wiem, że tak jest. Ale więcej niż wiem, bo i sam tego doświadczyłem w latach okupacji, kiedy byłem robotnikiem w tej części Krakowa, tutaj, opodal stąd - dobrze wiecie - niejednokrotnie wracając $\mathrm{z}$ pracy po nocnej zmianie, nawiedzałem ten kościół, przystępowałem tutaj do Komunii św. nieraz, wracając z pracy po nocnej zmianie

${ }^{19}$ APMNP, rkps [bez sygn.] Dekret erekcji parafii pod wezwaniem Matki Boskiej Nieustajacej Pomocy w Krakowie, Kraków 18 III 1983, kopia.

${ }^{20}$ APMNP, rkps [bez sygn.] Prośba o poparcie starañ..., s. 3-4; Kronika Parafii Matki Bożej Nieustajacej Pomocy w Krakowie, t. 1, s. 5; ARK, Kronika klasztoru (od 1988 r.).

${ }^{21}$ ARK, rkps [bez sygn.] Kronika klasztoru (od 1988 r.). 
i zapamiętalem sobie klimat tego kościoła. Tak, że nie tylko to wiem, wiem $\mathrm{z}$ informacji, ale wiem jakoś $\mathrm{z}$ własnego doświadczenia i myślę, że mam jakąś własną cząstkę w tym wielkim doświadczeniu w parafii św. Józefa, w parafii w Borku Fałęckim, w parafii wreszcie całego Krakowa, w tym wielkim doświadczeniu Nieustającej Pomocy. Wiem, że mam w tym jakąś cząstkę, jakąś małą, osobistą cząstkę w tym doświadczeniu"22.

Do wspomnień związanych z podgórską ikoną powrócił papież Jan Paweł II w spotkaniu z redemptorystami w dniu 30 czerwca $1991 \mathrm{r}$. w ich klasztorze przy kościele św. Alfonsa w Rzymie (via Merulana 31). „Przypominam sobie okres okupacji nazistowskiej w Polsce w czasie II wojny światowej - mówił Ojciec Święty - Pracowałem wówczas w jednej z fabryk w Krakowie. Po pracy, często wstępowałem do kościoła Redemptorystów, który mijałem w drodze do domu. W kościele tym modliłem się przed Obrazem Matki Bożej Nieustającej Pomocy, który uważam za wyjątkowo piękny. Będąc już kardynałem chętnie odwiedzałem wasz kościół i ten obraz. Często odprawialem tam nabożeństwa, udzielałem Komunii. Ta moja wizyta jest więc, jak widzicie, kontunuacją mojego młodzieńczego uwielbienia dla tej Ikony. Dziękuję Bożej Opatrzności i Matce Bożej Nieustającej Pomocy za okazanie mi szczególnej opieki w tych tak trudnych okolicznościach"23.

\section{STARANIA O KORONACJE OBRAZU}

Nieprzerwanie rozwijający się kult podgórskiej ikony Matki Bożej Nieustającej Pomocy i jego wpływ na życie religijne wiernych skłonił redemptorystów polskich do podjęcia starań o koronację obrazu koronami papieskimi lub biskupimi. W dniu 19 grudnia 1992 r. o. Leszek Gajda, prowincjał warszawskiej prowincji redemptorystów, zwrócił się do biskupa krakowskiego kard. Franciszka Macharskiego z prośbą o ,pobłogosławienie tym wysiłkom i doprowadzenie do koronacji ikony, która doznaje szczególnej czci ze strony wiernych Podgórza. Prowincjał pisał, że duszpasterze i wspólnota redemptorystów domu krakowskiego uważają akt koronacji koronami papieskimi lub biskupimi za niezwykly dar dla jeszcze większej czci Matki Bożej i dobra duchowego Ludu Bożego Podgórza a nawet Krakowa"24. W ślad za tą prośbą redemptoryści przesłali Kardynałowi obszerne opracowanie o charakterze historycznym i pastoralnym: „Relacja ...[o] niezwykłej czci jakiej doznaje Matka Najświętsza w kopii Cudownego Obrazu Matki Bożej Nieustającej

${ }^{22}$ ARK, rkps [bez sygn.] Kazanie kard. K. Wojtyty w czasie nawiedzenia obrazu Matki Bożej Częstochowskiej w kościele Redemptorystów w Krakowie w 1968 r., (tekst nieautoryzowany).

${ }^{23}$ Fragment przemówienia papicża Jana Pawła II przytoczony za Prośbq o poparcie starań o koronacje obrazu Matki Bożej Nieustajacej Pomocy w kościele Redemptorystów w Krakowie przedłożona Konferencji Plenarnej Episkopatu Polski [25-26 XI 1993], s. 43. (Kopia w APMNP).

${ }^{24}$ APMNP, rkps [bez sygn.] Prowincjat L. Gajda do biskupa krakowskiego kard. F. Macharskiego, Warszawa 19 XII 1992, kopia. 
Pomocy w Krakowie-Podgórzu w kościele parafialnym redemptorystów poświęcone czci Matki Bożej Nieustającej Pomocy w ich kościele w Krakowie", uzasadniające przydatność tego aktu dla większego ożywienia pobożności maryjnej wśród mieszkańców miasta i okolicy. Podkreślali w nim, że wierni przychodzący tam na nabożeństwa „są świadkami wielu łask i cudów, jakich dokonała tutaj Matka Najświętsza i aby wyrazić swoją wdzięczność dla Niej pragną koronacji tego łaskami słynącego obrazu". Biskup krakowski wraz ze wymienionym wyżej przełożonym warszawskiej prowincji Zgromadzenia Najśw. Odkupiciela zwrócili się do Konferencji Episkopatu Polski $\mathrm{z}$ obszernie udokumentowaną prośbą o poparcie starań o koronację obrazu Matki Bożej Nieustającej Pomocy w kościele Redemptorystów w Krakowie. W petycji tej zarysowali dziewięćdziesięcioletnią historię kultu podgórskiej ikony wykazując, że „Maryja tutaj obrała sobie tron rozdawnictwa łask a Jej obraz Nieustającej Pomocy zasługuje na najwyższe wyróżnienie - uroczystą papieską koronację". Podkreślali w niej, że następstwem koronacji będzie „ożywienie nabożeństwa wiernych Krakowa i archidiecezji do M[atki] B[ożej] N[ieustającej] Pomocy. Nabożeństwo to rozwijane umiejętnie i systematycznie, zwłaszcza w formie nieustannej nowenny, gromadzi przed obrazem Matki Bożej znaczną grupę wiernych, którzy mogą się stać zaczynem nowej ewangelizacji. Dobrze bowiem zrozumiane i praktykowane nabożeństwo do Matki Najświętszej jest przecież nie tylko modlitwa, ale także współdziałaniem z Maryją w dziele odkupienia. Spotkania modlitewne przed święta Ikoną są prawdziwą katecheza, która poucza i zachęca do apostolstwa" 25 .

Biskupi zebrani na Jasnej Górze na 265. Konferencji Episkopatu Polski w dniach 25-26 listopada 1993 r. opowiedzieli się za uwieńczeniem tego cudownego obrazu koronami papieskimi. Prymas Polski kard. Józef Glemp w imieniu Konferencji zwrócił się w dniu 2 grudnia owego roku do Ojca Świętego Jana Pawła II za pośrednictwem kard. Antonio Maria Javierre Ortas, prefekta Kongregacji Kultu Bożego i Dyscypliny Sakramentów, z prośbą o wydanie indultu apostolskiego zezwalającego na koronację. Prymas pisał, że biskupom znany jest kult jakim się cieszy wspomniany obraz i popierają prośbę Arcybiskupa Metropolity Krakowskiego ${ }^{26}$.

„Wspominając Twoje słowa o znajdującym się w krakowskim Podgórzu wizerunku Matki Bożej Nieustającej Pomocy wypowiedziane w roku 1991 podczas wizyty w kościele Sant'Alfonso w Rzymie: "Po pracy często wstępowałem do kościoła Redemptorystów, który mijałem w drodze do domu. W kościele tym modliłem się przed obrazem Matki Bożej Nieustającej Pomocy, który miałem za wyjątkowo piękny«, pokornie prosimy o możliwość przyozdobienia ikony papieskimi koronami" - pisali do Ojca Świętego Jana

${ }^{25}$ APMNP, rkps [bez sygn.] Prośba o poparcie starań o koronację..., s. 4-5.

${ }^{26}$ APMNP, rkps [bez sygn.] Prymas Polski kard. J. Glemp do prefekta Kongregacji Kultu Bożego i Dyscypliny Sakramentów kard. A. Javierre Ortas, Warszawa 2 XII 1993, kopia. 


\section{IOANNES-PAVLVS-PPIII}

\section{ad perpetuam rei memoriam.}

Suira illa paroccialis aedes Nanctissimo. Redemptori dicata loco Podgórze, Cracoivae in reqione, gratiosam imaginem - Beatac Nariai Tirqinis de Perpetuo Jucuirsu servat, quaim Christifideles pie colunt ccielestium graitiarum copiam sibi suisque a Deo exposcentes. De senten tia Congregationis de Culu Divino et Disciplina Sacramentorum, quam ratam habemus, A postolica Tostra potestate Venerabili Fratri Wostro Francisco S.R.'. Cardinali. Hacharshi, Archicpiscopo Cracoviensi, partes committimus ut imagini illi, . Tostro nomine et atictoritate pretiosam imponat coronam, iuxta probatum liturgicum ritum. Confidimus sane Nos fore ut fideles istius. Provinciae ad Beatam Verqinem Mariam colendam maqisque incitentur. Contrarits quibusvis nihil obstartibus. Datum Romae, apud Sanctum Petrum, sub anuls Piscatoris, die quarto dicimo mertsis i 'thair, anno MCMKCIV, Zortificatus . Tostri sexto decimo.

- Angelus cará. Lodano

Fing Jecretarmas flatus

3. Brewe koronacyjne. 
Pawła II kard. Franciszek Macharski i jego biskupi pomocniczy: Stanisław Smoleński, Albin Małysiak, Kazimierz Nycz i Jan Szkodoń. „Obraz ten do dnia dzisiejszego cieszy się czcią i żywym kultem. Akt koronacyjny jest pragnieniem wszystkich tych, którzy tutaj się modlą"27.

Kard. F. Macharski dnia 18 stycznia 1994 r. zwrócił się do do kard. Antonia Marii Javierre'a Ortas, prefekta Kongregacji Kultu Bożego i Dyscypliny Sakramentów z gorącą prośbą o zezwolenie na uroczyste uwieńczenie papieskimi koronami wspomnianej łaskami słynącej ikony Najśw. Dziewicy. „Przez dziewięćdziesiąt lat kult Matki Bożej Nieustającej Pomocy w podgórskim obrazie jest ciagły i stale żywy i stąd promieniuje na całą archidiecezje” - pisał pasterz Kościoła krakowskiego. „Wierni są przekonani o Jej czułej, macierzyńskiej opiece i potężnym wstawiennictwie przed Bogiem, o czym świadczą zebrane podpisy. Mając to wszystko na uwadze, jak również rolę pobożności maryjnej w dziele nowej ewangelizacji” Kardynał jeszcze raz prosił o upoważnienie go do dokonania koronacji tej ikony. Do prośby dołączono wspomniane już pismo Konferencji Episkopatu Polski, krótki rys historyczny kultu obrazu i prośby duchowieństwa i wiernych o koronację $e^{28}$.

\section{KORONACJA OBRAZU}

Redemptoryści zadbali o duszpasterskie przygotowanie wiernych do uroczystości koronacyjnych. Opracowali specjalne Rozważania majowe przed koronacja Obrazu Matki Bożej Nieustajacej Pomocy w Krakowie (Kraków 1994), wydane przez Wydział Duszpasterstwa Kurii Metropolitalnej. Książeczka zawierała siedem czytanek: „Geneza kultu Matki Bożej po wezwaniem Nieustającej Pomocy; Teologiczna treść obrazu Matki Bożej Nieustającej Pomocy; Początki kultu Matki Bożej Nieustającej Pomocy na ziemiach polskich i w Krakowie; Rozwój kultu Matki Bożej Nieustającej Pomocy w Podgórzu; Nieustanna Nowenna do Matki Bożej Nieustającej Pomocy; Dlaczego koronacja?; Znaczenie koronacji obrazu Matki Bożej Nieustającej Pomocy".

W dniu 18 maja 1994 r. Wydział Historii Kościoła Papieskiej Akademii Teologicznej w Krakowie wraz z Wyższym Seminarium Duchownym Redemptorystów urządził sesję naukową „Kult Matki Bożej Nieustającej Pomocy wczoraj i dzis". Inicjatorami i organizatorami tego spotkania w kościele Redemptorystów byli ks. doc. dr hab. Stanisław Piech, dziekan Wydziału, kierownik Katedry Dziejów Kultury Religijnej wraz ze swym asystentem o. mgr-lic. Marianem Sojka, rektorem krakowskiego domu redemptorystów. Sesję otworzył kard. Franciszek Macharski, metropolita krakowski. Referaty

${ }^{27}$ ARK, rkps [bez sygn.] Prośba kard. F. Macharskiego i jego biskupów pomocniczych do Ojca Świętego Jana Pawła II o możliwość przyozdobienia ikony papieskimi koronami, kopia (bez daty).

18 I 1994.

\footnotetext{
ARK, rkps [bez sygn.] Kard. F. Macharski do kard. A. Javierre Ortas, Kraków
} 
wygłosili: o. doc. dr hab. Benignus Józef Wanat OCD, Teologia ikony Matki Bożej Nieustajqcej Pomocy; o. Marian Sojka, Kult Matki Bożej Nieustajqcej Pomocy w Kościele powszechnym; o. dr Edward Nocuń CSsR, Cześć Matki Bożej Nieustajacej Pomocy w Kościele polskim; o. dr Antoni Bazielich CSsR, Stuga Boży Bernard Eubieński jako propagator kultu Matki Bożej Nieustajacej Pomocy; ks. Stanisław Piech, Kult Matki Bożej Nieustającej Pomocy w kościele Redemptorystów w Krakowie-Podgórzu; o. dr Leszek Gajda CSsR, prowincjał, Jak dziś mówić o Maryi? - Matka Boża w kaznodziejstwie współczesnym; o. dr Stanisław Madeja CSsR, Nieustanna Nowenna forma kultu maryjnego. Sesja zakończyła się nabożeństwem nieustannej nowenny i uroczystą Mszą św. koncelebrowaną pod przewodnictwem kard. F. Macharskiego, który także wygłosił homilię.

Przed koronacją wygłoszono w kościele Redemptorystów misje, a po nich odbywała się nowenna. W niedziele (19 VI) pielgrzymowały rodziny zakonne męskie i żeńskie. Modlitwom przewodniczył o. Andrzej Rębacz CSsR. W tygodniu ikonę Matki Bożej Nieustającej Pomocy nawiedzały poszczególne parafie dekanatów podgórskiego i prokocimskiego. W poniedziałek (20 VI) pielgrzymowały parafie: Bieżanów Nowy (św. Rodziny), Borek Fałęcki (Matki Boskiej Zwycięskiej), Kosocice (św. Marii Magdaleny). Przewodniczył bp. Jan Szkodoń. We wtorek przybyły parafie: Kurdwanów (Podwyższenia Krzyża św.), Cegielniane (Matki Bożej Saletyńskiej) i Bieżanów Stary (Narodzenia Najśw. Maryi Panny). Modlitwie przewodził bp Albin Małysiak. We środe przyszli wierni z Prokocimia Nowego ( $\mathrm{z}$ parafii Miłosierdzia Bożego) i Starego (Matki Bożej Dobrej Rady) i Wróblowic (Przemienienia Pańskiego). Przewodniczył o. Leszek Gajda CSsR. We czwartek pod przewodnictwem bpa Stanisława Smoleńskiego modlili się pielgrzymi z parafii: św. Józefa w Podgórzu, Niepokalanego Serca Najśw. Maryi Panny w Rybitwach, Nawiedzenia Najśw Maryi Panny w Rżące i Ducha św. w Podstolicach. W piątek były parafie: Swoszowice (Opatrzności Bożej), Wola Duchacka (Zmartwychwstania Pańskiego), Piaski Wielkie (Najśw. Serca Jezusowego). Przewodniczył bp Kazimierz Nycz. W sobotę z o. L. Gajdą modlili się parafianie z Płaszowa (Najśw. Serce Jezusowe), Łagiewnik (Najśw. Serce Jezusowe) i Piaski Nowe (Matka Boża Różańcowa). Pielgrzymi uczestniczyli w nieustannej nowennie a następnie we Mszy św ${ }^{2}$. Słuchali występów chórów i koncertów w wykonaniu artystów scen krakowskich $^{30}$. Dzień nowennowy kończył się Apelem Maryjnym. Warto

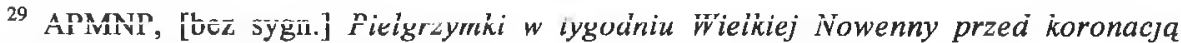
w kościele oo. Redemptorystów, afisz.

${ }^{30}$ W niedzielę (19 VI 1994) śpiewał „Chór Mariański” z parafii Matki Bożej z Lourdes, w poniedziałek odbył się „Koncert religijnej muzyki dawnej” w wykonaniu Izabeli Szota (sopran) Pawła Iwaszkiewicza (flet prosty) i Anny Marcisz (wirginał); w wtorek słuchano „Koncertu oratoryjnego „Stabat Mater” G. B. Pergolesiego (wykonawcy: I. Szota - sopran, Ewa Wolak - alt oraz zespól kameralny pod dyrekcją Tomasza Chmiela); we środę na koncert zlożyły się; Ave Maria - F. Schubert, Ave Maria - J. S. Bacha i C. Gounod, Jesu spes mea M. Sęp Sarzyński oraz koncert na dwie gitary i orkiestrę (wykonawcy: I. Szota - sopran, Kon- 
wspomnieć, że w okresie 19-25 czerwca każdy dzień nowennowy miał swój temat $\mathrm{z}$ odpowiednim mottem biblijnym stanowiącym podstawe do kazań i modlitw. Warto po kolei przytoczyć te tematy: Matka - Oto Matka twoja (J 19, 27); Wzór życia ludzi odkupionych - Badź pozdrowiona, petna laski Pan z Tobq (Lk 1, 28); Wzór chrześcijańskiej miłości - Niech mi się stanie wedtug słowa Twego (Łk 1,38); Miłość chrześcijańska fudamentem postaw ludzkich i małżeńskich - Nie bój się wziq̨ć do siebie Maryi (Mt 1, 20); Bóg, rodzice i dzieci w chrześcijańskiej rodzinie - Powinienem być w domu Ojca mego (Lk 2, 49); Rodzicielski stosunek do fundamentalnych wyborów, realizacja życiowego powołania dzieci - Kto czyni wolę Ojca [...], ten mi jest bratem, siostrq i matkq (Mt 12, 50); Maryja wzorem apostołów i apostołowanych - W tym czasie wybrata sie Maryja $w$ droge (Lk 1, 39), Wszyscy oni trwali jednomyślnie na modlitwie [...] z Maryja, Matka Jezusa (Dz 1, 14) ${ }^{31}$. Tematyka ta była odzwierciedleniem toczonej wówczas w Polsce walki o uszanowanie w ustawodawstwie państwowym prawa do życia dla każdego poczętego człowieka.

W niedzielę poprzedzającą koronację na Mszach św. we wszystkich kościołach i kaplicach archidiecezji krakowskiej zostało odczytane Słowo kard. F. Macharskiego o koroonacji obrazu. „W blisko już 1000-letniej historii diecezji krakowskiej pojawia się nowy znak miłosiernej Bożej obecności” pisat Metropolita. „Jest to znak maryjny: koronacja papieskimi koronami Matki Bożej Nieustającej Pomocy w kościele oo. Redemptorystów na Podgórzu. [...] Wraz z ojcami Redemptorystami zapraszam serdecznie: przyjdźcie ten znak zobaczyć, uradować się nim i odczytać wezwanie, jakie nam przynosi. - Będzie to dla nas okazja do publicznego i uroczystego wyznania wiary w Jezusa Chrystusa, Odkupiciela człowieka, który wezwał do współdziałania swoją Matkę, a razem z Nią cały lud Boży; będzie to wielkie dziękczynienie Kościoła krakowskiego za powołanie na Stolicę Apostolską w Rzymie Jana Pawła II, i równocześnie nasza wielka modlitwa za umiłowanego Ojca Świętego; będzie to publiczne podziękowanie za rozliczne łaski otrzymane dzięki modlitwie przed wizerunkiem Matki Bożej Nieustającej Pomocy w Jej podgórskim sanktuarium; będzie to dzień naszego zawierzenia na nowo Matce Bożej Krakowa z Podgórzem, i całej Ojczyzny, by była królestwem Jezusa i Maryi, i by mimo rozlicznych trudności mogła się rozwijać w pełnej wolności i pokoju"32. W przeddzień koronacji o północy odprawiono pasterkę maryjna.

rad Szota - baryton i orkiestra kameralna pod dyrekcją Jana Baryły); we czwartek zaprezentowano „Mszę G-dur" Franciszka Schuberta (wykonawcy: I. Szota - sopran, A. Zamojska sopran, Ewa Wolak - alt, Witold Wrona - tenor, Marcin Wolak - bas, wraz z zespołem kameralnym pod dyrekcją $\mathrm{T}$. Chmiela, w piątek i sobotę program artystyczny przygotowali klerycy tuchowscy. (APMNP, „Występy artystyczne” Afisze koncertów).

${ }^{31}$ APMNP, [bez sygn.] Nowenna przed koronacja obrazu Matki Bożej Nieustającej Pomocy, afisz.

${ }^{32}$ APMNP, [bez sygn.] Słowo Księdza Kardynała przed koronacja papieskimi koronami cudownego obrazu Matki Bożej Nieustajacej Pomocy z kościola Ojców Redemptorystów w Krakowie - Podgórzu, Kraków 18 V 1994. 


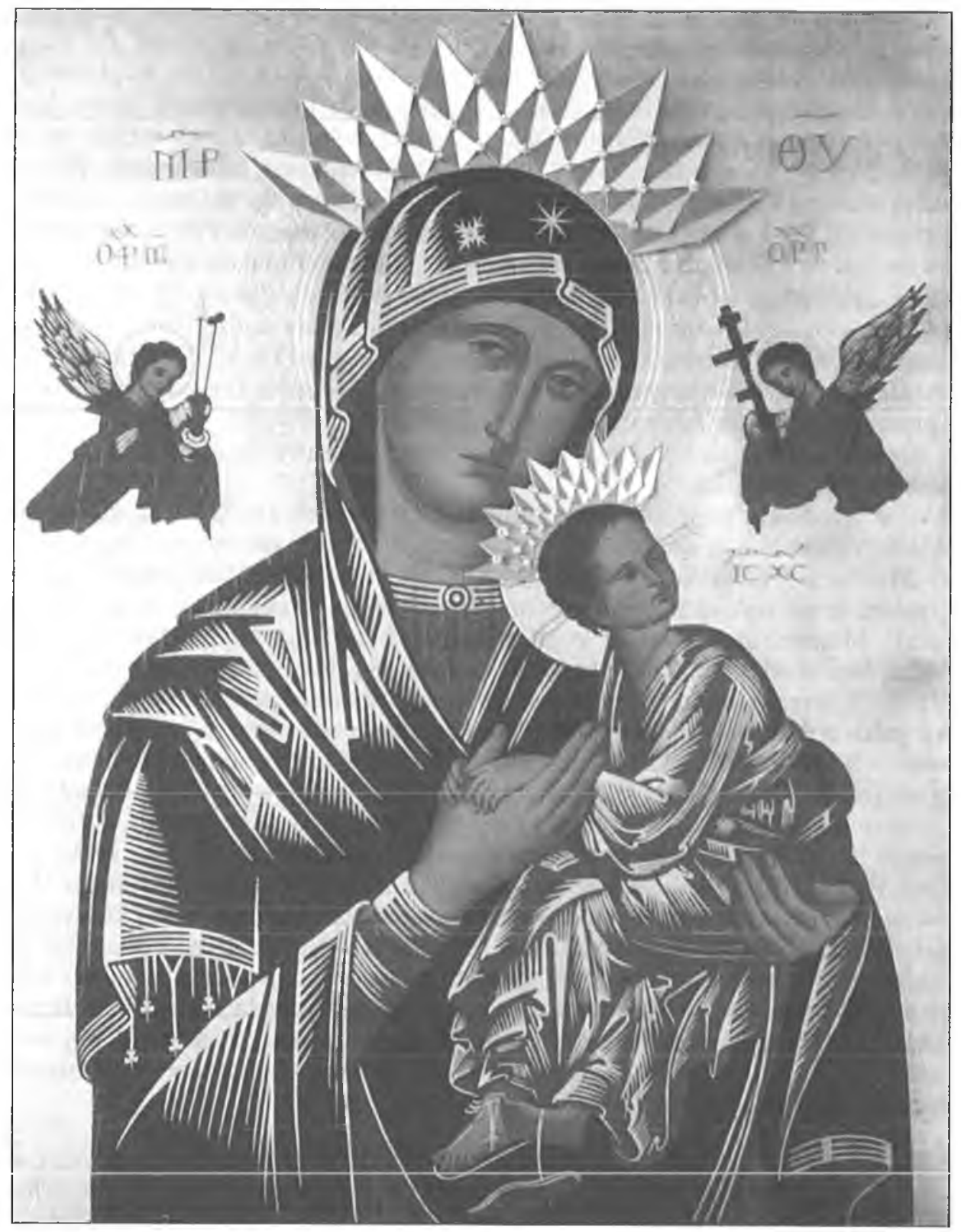

4. Ikona Matki Bożej Nieustającej Pomocy w kościele Redemptorystów w Krakowie, po koronacji w $1994 \mathrm{r}$. 
W upalną niedzielę 26 czerwca 1994 r. o godz. 11.15 przy dźwięku dzwonów wyruszyła $\mathrm{z}$ kościoła Redemptorystów procesja na Rynek Podgórski, gdzie przy specjalnie zbudowanym ołtarzu polowym przed fasadą kościoła św. Józefa miała się dokonać koronacja cudownego obrazu. Ikonę Matki ożej nieśli kolejno bracia klerycy (redemptoryści), dziewczęta, młodzieńcy, mężczyźni i kobiety.

Licznie przybyli pielgrzymi z terenu archidiecezji krakowskiej zapełnili Rynek Podgórski. W południe rozpoczęła się uroczysta koncelebrowana Msza św. koronacyjna pod przewodnictwem metropolity krakowskiego, a kazanie wygłosił abp Stanisław Nowak, metropolita częstochowski. Kaznodzieja nazwał koronację aktem zawierzenia Maryi, która jest znakiem wielkiej nadziei.

Po homilii odczytano telegram Ojca św. „Uczestniczę duchowo w modlitwie Ludu Bożego Miasta Krakowa, który w dzisiejszą niedzielę gromadzi się pod przewodnictwem swego Arcypasterza na uroczystej koronacji Obrazu Matki Bożej Nieustającej Pomocy w kościele Ojców Redemptorystów na Podgórzu” - pisał papież. „Kościół ten i czczony w nim Obraz Matki Bożej zapisał się głęboko w mojej pamięci, gdy w czasie okupacji, jako robotnik fabryki Solvay i równocześnie kleryk tajnego Seminarium Duchownego, po nocnych zmianach przychodziłem tutaj na poranną Mszę św. W tamtych trudnych czasach Maryja była dla nas w sposób szczególny pomocą nieustającą i niezawodną we wszystkich potrzebach. Doświadczyłem tego nie jeden raz. Dzisiaj pragnę wspólnie z Ludem Bożym Miasta Krakowa zawierzyć Maryi wszystkie trudne sprawy Ojczyzny i Kościoła doby obecnej, a zwłaszcza polską rodzinę, w tej chwili ponownie zagrożoną u samych korzeni jej egzystencji i jej podstawowych praw. Modlę się wraz z Wami, aby polskie rodziny stały na straży każdego poczętego życia; aby to podstawowe prawo każdej ludzkiej istoty, jakim jest naturalne prawo do życia, było uszanowane także w polskim ustawodawstwie",33.

Prowincjał o. Leszek Gajda poprosił Kardynała o dokonanie koronacji. Odczytano brewe koronacyjne, w którym papież Jan Paweł II zatwierdził orzeczenie Kongregacji Kultu Bożego i Dyscypliny Sakramentów zezwalające na koronację łaskami słynącej ikony i upoważnił kard. F. Macharskiego do nałożenia koron w jego imieniu. Arcybiskup krakowski poświęcił korony i w ciszy włożył je na głowy Dzieciątka Jezus i Jego Niepokalanej Matki.

Kustosz sanktuarium złożył ślubowanie. „W kolejnym roku Wielkiej Nowenny przed 2000 rokiem przyjścia na świat naszego Zbawiciela Pána Jezusa Chrystusa, poświęconym uświęceniu rodziny i 1000-lecia Kościoła krakowskiego, w naszej obecności dokonano historycznego aktu uwielbienia Bogarodzicy Maryi, Matki Bożej Nieustającej Pomocy, przez nałożenie na Jej skronie i Jezusa koron papieża Jana Pawła II" - mówił proboszcz. „W tym ważnym momencie dziejów Kościoła podgórskiego i całej Ziemi Krakowskiej, w poczuciu odpowiedzialności za rozsławienie czci Matki

${ }^{33}$ APMNP, [bez sygn.] Telegram papieża Jana Pawła II do kard. F. Macharskiego, Watykan 21 VI 1994, kopia. 
Bożej, wzorem redemptorystów minionych lat, ja o. Michał Reinke, kustosz sanktuarium Matki Bożej Nieustającej Pomocy i proboszcz tejże parafii, w imieniu całej wspólnoty redemptorystów i wszystkich moich następców, przysięgam i ślubuję, że dołożę wszelkich starań, aby Matka Boża Nieustającej Pomocy, obecna w kościele »na górce«, była znana, czczona i kochana, nie tylko w naszej metropolii krakowskiej, ale również w całej ojczyźnie, będąc wiernym zobowiązaniu jakie nadał papież Pius IX powierzając przed laty obraz zgromadzeniu Redemptorystów: „Sprawcie, aby ten obraz poznano w świecie i aby się w nim rozmiłowano". Równocześnie zawierzam Matce Bożej Nieustającej Pomocy w dniu Jej koronacji wszystkich czcicieli gromadzących się w naszym sanktuarium redemptorystów na Podgórzu, a także innych świątyniach, na nabożeństwach Nieustannej Nowenny, szczególnie nasze katolickie rodziny: małżonków, młodzież i dzieci. Bądź dla wszystkich Matką Nieustającej Pomocy, Przewodniczką na drodze wiary i miłości oraz Królową. Tak mi dopomóż Bóg i Święta Ewangelio"34.

W uroczystości wzięli także udział biskupi: Kazimierz Górny, pasterz Kościoła rzeszowskiego, biskupi pomocniczy archidiecezji krakowskiej: Julian Groblicki, Albin Małysiak, Stanisław Smoleński i Jan Szkodoń oraz biskup senior Piotr Bednarczyk z Tarnowa. Były delegacje Papieskiej Akademii Teologicznej (księża: prof. dr hab. Jan Dyduch, doc. dr hab. Stefan Koperek prorektorzy i doc. dr hab. Stanisław Piech dziekan Wydziału Historii Kościoła) i Akademii Teologii Katolickiej oraz przedstawiciele rodzin zakonnych. Był konsul Austrii Emil Brix z małżonką. Przybyły delegacje władz Krakowa $z$ prezydentem miasta Józefem Lasotą i wojewodą Tadeuszem Piekarzem. Bezpośrednią transmisję $\mathrm{z}$ uroczystości przeprowadziły „Radio Maryja” i „Radio Mariackie”. Po Mszy św. ikonę przenesiono do kościoła św. Józefa. Wieczorem po Mszy św. odbyła się procesja z koronowanym obrazem do kościoła Redemptorystów. Uroczystości zakończyły się Apelem Maryjnym.

Była to czwarta w Polsce ikona Matki Bożej Nieustającej Pomocy ozdobiona papieskimi koronami. Wcześniej ukoronowane zostały obrazy w farze poznańskiej (11 X 1961), w Toruniu w kościele Redemptorystów na Bielanach (1 X 1967), w kościele Karmelitanek Bosych w Kaliszu-Niedźwiadach. Ten ostatni ukoronował sam papież Jan Paweł II w dniu 7 czerwea 1991 r. we Włocławku, w czasie swojej czwartej pielgrzymki do Ojczyzny. Kraków religijny wzbogacił się o siódmy już wizerunek Maryi ukoronowany papieskimi koronami (Matka Boża „Piaskowa” w kościele Karmelitów - 8 IX i 88 83, „Smęina Dobrodziejka" w bazyíice Franciszikanów Konwentualnych 20 IX 1908, Matka Boża Różańcowa w bazylice Dominikanów - 2 X 1921, Matka Boża Świętojańska od Wykupu Niewolników, kościół Prezentek - 9 V 1965, Matka Boża Częstochowska z kościoła Mariackiego - 15 XII 1968, statua Matki Bożej Fatimskiej - Nowa Huta, Bieńczyce „Arka Pana” - 13 IX

${ }^{34}$ APMNP, [bez sygn.] Tekst ślubowania. 
1992. Kult Matki Bożej Nieustającej Pomocy czczonej w podgórskiej ikonie obejmuje swoim zasięgiem głównie archidiecezję krakowską. W ciągu roku przybywa do sanktuarium około 30 zorganizowanych grup pielgrzymkowych liczących razem około tysiąca pątników ${ }^{35}$.

Warto dodać, że pięć lat po koronacji na krakowskim Podgórzu Ojciec Święty Jan Paweł II ukoronował w dniu 16 VI 1999 r. na rynku wadowickim kolejną ikonę Matki Bożej Nieustającej Pomocy przed którą się modlił w tamtejszym kościele parafialnym latach swojej młodości.

${ }^{35}$ APMNP, [bez sygn.] Odpowiedzi na kwestionariusz Kurii Metropolitalnej $w$ Krakowie o sanktuarium, 1998. 